\title{
EFFECTS OF PROSTAGLANDINS ON EXCITATORY TRANSMISSION IN ISOLATED CANINE TRACHEAL MUSCLE
}

\author{
Hironori NAKANISHI, Hirohide YOSHIDA*, Norimichi NAKAHATA \\ and Takehiko SUZUKI \\ Department of Pharmacology, Fuhushima Medical College and *Pharmucy. \\ Fukushima Medical College Hospital, Fukushima 960, Japan
}

Accepted May 24, 1978

\begin{abstract}
Contractile response of the isolated canine tracheal muscle to transmural nerve stimulation was considerably depressed by $10^{6} \mathrm{~g} / \mathrm{ml}$ of prostaglandin $A_{1}\left(P A_{1}\right)$, $\mathrm{A}_{2}\left(\mathrm{PGA}_{2}\right), \mathrm{B}_{2}\left(\mathrm{PGB}_{2}\right), \mathrm{E}_{1}\left(\mathrm{PGE}_{1}\right), \mathrm{E}_{2}(\mathrm{PGE})$ and $\mathrm{F}_{2, t}\left(\mathrm{PGF}_{2 k}\right)$, whilc the response to exogenously administered $\mathrm{ACh}$ was only slightly affected by the pretreatment with prostaglandins (PGs). The order of the potency of the depressive effect was as follows; $\mathrm{PGE}_{1}>\mathrm{PGE}_{2}>\mathrm{PGA}_{1}>\mathrm{PGA}_{2} \div \mathrm{PGB}_{2} \div \mathrm{PGF}_{2}$. Therefore, if a negative feedback control mechanism through prostaglandins exists in the excitatory transmission in canine tracheal muscle, the PGE scries may predominantly operate the mechanism. Indomethacin in a dose of $10^{-6} \mathrm{~g} / \mathrm{ml}$ produccd a potentiation of the contractile responses to transmural nerve stimulation and to exogenously administered ACh.
\end{abstract}

It has been observed that prostaglandin $E_{1}\left(P E_{1}\right)$ and $E_{2}\left(P_{G} E_{2}\right)$ suppressed cardiac acceleration and release of noradrenaline (NA) in response to sympathetic nerve stimulation in isolated rabbit hearts (1-5). Similar findings have also been observed in the spleen (3, 6), vas deferens $(3,7,8)$ and blood vessels $(9)$ in various spccics. $\mathrm{PGE}_{1}$ and $\mathrm{PGE}_{2}$ are also released by the nerve stimulation $(10,11)$. Therefore, it has been postulated that the released PGE series act on the prejunctional site and control the subsequent release of NA (5). Recently, the existence of a similar negative feedback mechanism was suggested in parasympathetic nerves innervating rabbit and mouse hearts (12-14).

On the other hand, broncho-constriction in situ in response to parasympathetic nerves was prevented by $\mathrm{PGE}_{1}$ in rabbits and guinca-pigs (15). $\mathrm{PGE}_{1}$ and $\mathrm{PGE}_{2}$ prevented the contractile response of the isolated canine tracheal muscle to transmural nerve stimulation (16).

The present study was undertaken to investigate the effects of other prostaglandins (PGs) on the contractile responses to transmural nerve stimulation and to exogenously administered $\mathrm{ACh}$ in isolated canine tracheal muscle.

\section{MATIRIALS AND METHODS}

Mongrel dogs of either sex, weighing 8 to $15 \mathrm{~kg}$ were anesthetized with pentobarbital sodium (35 $\mathrm{mg} / \mathrm{kg}$, i.v.) and exsanguinated from the bilateral common carotid arteries. The cervical trachea was excised. Recording of the muscle contraction was made using 
the same method previously described (16). Briefly, in order to obtain the cumulative dose-response curve of $\mathrm{ACh}$, a strip of tracheal circular muscle (approx. $1.0 \times 0.2 \mathrm{~cm}$ ) was suspended in Krebs-Ringer bicarbonate solution $(20 \mathrm{ml})$, bubbled with a mixture of $95 \%$ $\mathrm{O}_{2}$ and $5 \% \mathrm{CO}_{2}$, and kept at $36^{\circ} \mathrm{C}$. To stimulate the nerve transmurally, the muscular strip was hung between two platinum rings and immersed in Krebs-Ringer bicarbonate solution. The composition of the solution was as follows; $\mathrm{NaCl}, 119 \mathrm{mM} ; \mathrm{CaCl}_{2} \cdot 2 \mathrm{H}_{2} \mathrm{O}$, $2.5 \mathrm{mM} ; \mathrm{KH}_{2} \mathrm{PO}_{4}, 1.2 \mathrm{mM} ; \mathrm{KCl}, 4.7 \mathrm{mM} ; \mathrm{MgSO}_{4} \cdot 7 \mathrm{H}_{2} \mathrm{O}, 1.2 \mathrm{mM}$; $\mathrm{NaHCO}_{3}, 25 \mathrm{mM}$ and glucose, $11 \mathrm{mM}$. Contraction of the muscle was recorded on a smoked drum, using an isotonic lever. The stimulation parameters used were $30 \mathrm{~Hz}, 1 \mathrm{msec}, 25$ volts $/ \mathrm{cm}$ and for $30 \mathrm{sec}$. The final concentration of the drugs was expressed in $\mathrm{g} / \mathrm{ml}$. The differences between the values obtained were analyzed using Student's $t$-test.

Drugs used were acetylcholine chloride $(\mathrm{ACh})$, prostaglandin $\mathrm{A}_{1}\left(\mathrm{PGA}_{1}\right)$, prostaglandin $A_{2}\left(P A_{2}\right)$, prostaglandin $B_{2}\left(P_{2} B_{2}\right)$, prostaglandin $E_{1}\left(P_{1} E_{1}\right)$, prostaglandin $E_{2}\left(P_{2} E_{2}\right)$, prostaglandin $\mathrm{F}_{2 \alpha}\left(\mathrm{PGF}_{2 \alpha}\right)$ and indomethacin (Sumitomo Chemical Co.). Prostaglandins (PGs, Ono Pharmaceutical Co.) were stocked as $2 \%$ solution in $20 \%$ ethyl alcohol (vehicle), and diluted with distilled water just before administration. Indomethacin was dissolved in a weak basic solution ( $\mathrm{pH} 8.5$ ) adjusted by $\mathrm{NaOH}$, and used as a stock solution.

\section{RESULTS}

I. Effects of PGs on the contractile response to exogenously administered $A C h$

PGs rarely produced any effect on the tone of the isolated tracheal muscle. However, when the muscular tone was elevated by $10^{-6} \mathrm{~g} / \mathrm{ml}$ of ACh, more than $10^{-6} \mathrm{~g} / \mathrm{ml}$ of $\mathrm{PGE}_{1}$ produced a relaxation. The pretreatment (10 min before) of $10^{-5} \mathrm{~g} / \mathrm{ml}$ of $\mathrm{PGA}_{1}, \mathrm{PGA}_{2}$, $\mathrm{PGB}_{2}$ or $\mathrm{PGF}_{2 \alpha}$ slightly depressed the contractile response to exogenously administered $\mathrm{ACh}$

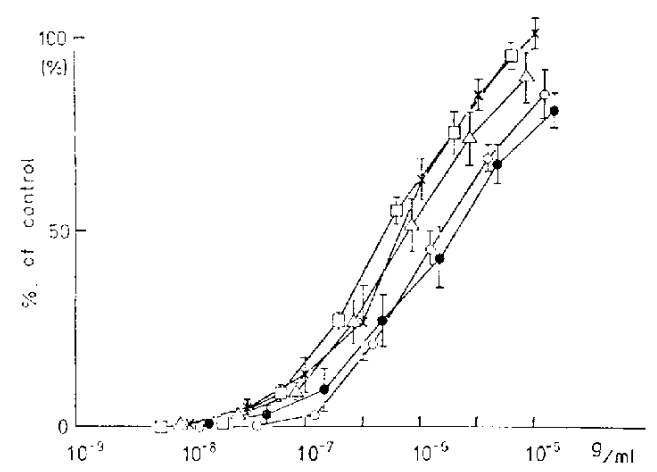

FIG. 1. Effects of $\mathrm{PGA}_{1}, \mathrm{PGA}_{2}, \mathrm{PGB}_{2}$ and $P G F_{2 \alpha}$ on the contractile response of isolated tracheal muscle of dogs to exogenously administered $\mathrm{ACh}$. Ordinate; $\%$ of maximum response obtained in untreated group. Abscissa; doses of ACh $(\log \mathrm{g} / \mathrm{ml}) . \quad x-\times$; Vchicle (equi-volume of the solvent with $10^{-5} \mathrm{~g} / \mathrm{ml}$ of PGs). $-\mathrm{O} ; \mathrm{PG} \Lambda_{1}\left(10^{-5} \mathrm{~g} / \mathrm{ml}\right)$ treated group. $-\mathrm{PG} \Lambda_{2}\left(10^{-5} \mathrm{~g} /\right.$

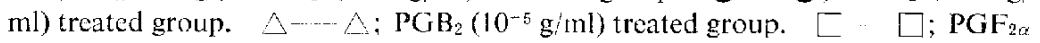
$\left(10^{-5} \mathrm{~g} / \mathrm{ml}\right)$ treated group. Each point shows the mean-standard error (Number of animals $=4$ ). 
(cumulative method). However, the inhibition was statistically not significant from the inhibition induced by the vehicle (equi-volume of the solvent with $10^{-5} \mathrm{~g} / \mathrm{ml}$ of PGs) (Fig. 1). The pretreatment with $10^{-6} \mathrm{~g} / \mathrm{ml}$ of $\mathrm{PGE}_{1}$ or $\mathrm{PGE}_{2}$ had almost no effect on the contractile response to $\mathrm{ACh}$, thus confirming the previous finding (16).

II. Effects of PGs on the contractile response to transmural nerve stimulation

The administration of $10^{-6} 1010^{-5} \mathrm{~g} / \mathrm{ml}$ of $\mathrm{PGA}_{1}$ depressed the contractile response to

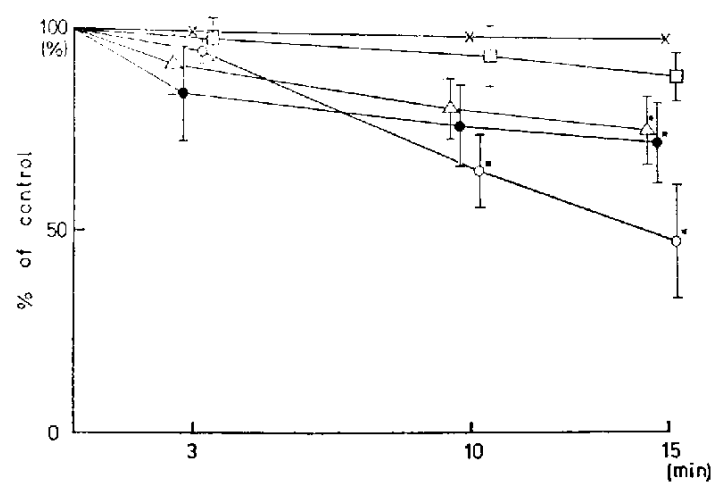

FIG. 2. Effects of $P G A_{1}$ and $P G \Lambda_{2}$ on the contractile response of isolated tracheal muscle to field stimulation in dogs. Ordinate; \% of control (the height of contraction induced by ficld stimulation beforc drug administration was 100). Abscissa; time course after drug administration $(\mathrm{min}) . \quad x-\ldots$; Vehicle (equi-volume of the solvent with $10^{-5} \mathrm{~g} / \mathrm{ml}$ of PGs) treated group. O- $\mathrm{PGA}_{1}\left(10^{-5} \mathrm{~g} / \mathrm{ml}\right)$ treated group. - $; \mathrm{PGA}_{1}\left(10^{-6} \mathrm{~g} / \mathrm{ml}\right)$ treated group. $\mathrm{A} \wedge ; \mathrm{PGA}_{2}$ $\left(10^{5} \mathrm{~g} / \mathrm{ml}\right)$ treated group. $\square \square \square ; \mathrm{PGA}_{2}\left(10^{-6} \mathrm{~g} / \mathrm{ml}\right)$ treated group. Fach point shows the mean $\perp$ standard error (Number of animals--4). $\quad * \mathrm{P}<0.05$; significantly differed from the value of vehicle treated group.

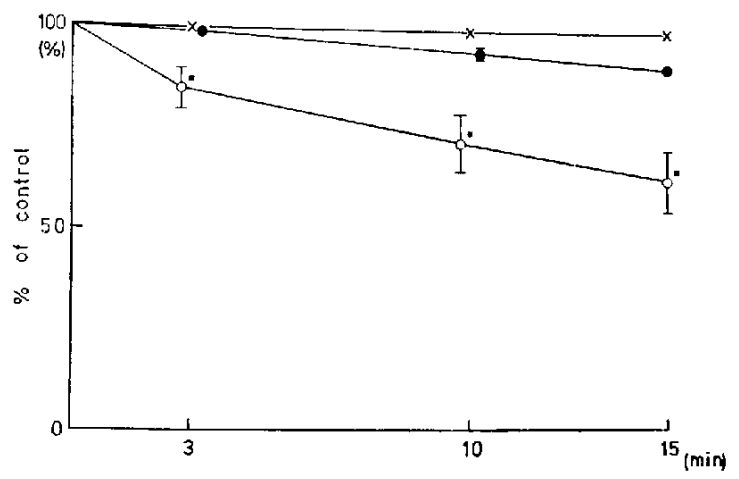

FIG. 3. Effect of $\mathrm{PGB}_{2}$ on the contractile response of isolated tracheal muscle of dogs to field stimulation. Ordinate; $\%$ of the control (the height of contraction induced by field stimulation before drug administration was 100). Abscissa; time course after drug administration (min). $\times-\cdots-. \times$; Vchicle (cqui-volume of the solvent with $10^{-5} \mathrm{~g} / \mathrm{ml}$ of $\left.\mathrm{PGB}_{2}\right)$ treated group. $0 \cdots--\mathrm{PGB}_{2}\left(10^{-5} \mathrm{~g} / \mathrm{ml}\right)$ treated group. - $\mathrm{PGB}_{2}\left(10^{-6} \mathrm{~g} / \mathrm{ml}\right)$ treated group. Each point shows the mean $t$ standard error (Number of animals -4 ). $* \mathrm{P}<0.05$; significantly differed from the value of vehicle treated group. 


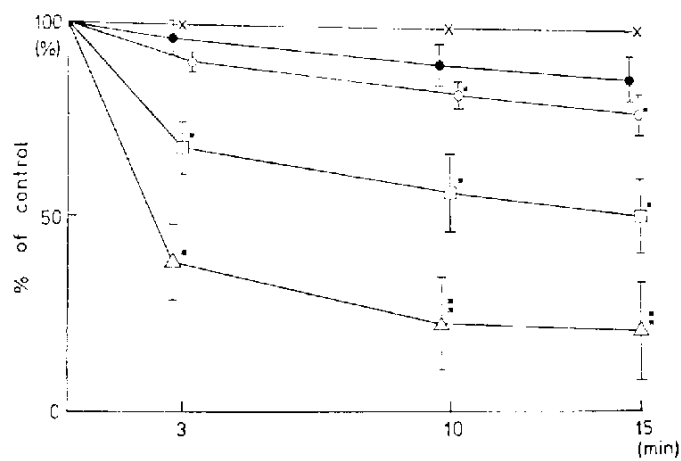

FIG. 4. Effects of $\mathrm{PGE}_{1}, \mathrm{PGE}_{2}$ and $\mathrm{PGF}_{2 \alpha}$ on the contractile response of isolated tracheal muscle to field stinulation in dogs. Ordinate: $\%$ of the control (height of contraction induced by ficld stimulation before drug administration was 100). Abscissa; time course after drug administration (min). $\times \quad x$; Vehicle (equivolume of the solvent with $10^{-6} \mathrm{~g} / \mathrm{ml}$ of PGs) troated group. $\quad$; PGF $2 \alpha$ $\left(10^{-7} \mathrm{~g} / \mathrm{ml}\right)$ treated group. $--O \mathrm{PGF}_{2 \alpha}\left(10^{-6} \mathrm{~g} / \mathrm{ml}\right)$ treated group. $\mathrm{A}$. $\mathrm{A}$; PGE $_{1}\left(10^{-6} \mathrm{~g} / \mathrm{ml}\right)$ treated group. $\Pi \cdot \Pi ; \operatorname{PGE}_{2}\left(10^{-5} \mathrm{~g} / \mathrm{ml}\right)$ treated group. Each point shows the mean \pm standard error (Number of animals $=4$ ). $* P<0.05$, $* * \mathrm{P}<0.02$; significantly differed from the value of the vehicle treated group.

transmural nerve stimulation. The depressive effect progressed according to the time course after administration of the drug. The contractile response was reduced to $71.5 \pm 10.1 \%$ and $47.2+13.8 \%$ (the mean \pm S.E., $N=4$ ), respectively, 15 min after the administration of $10^{-6}$ and $10^{-5} \mathrm{~g} / \mathrm{ml}$ of $\mathrm{PGA}_{1}$ (Fig. 2). These values were statistically significant from the value obtained by the vehicle $(\mathrm{P}<0.05)$.

The administration of $10^{-5}$ to $10^{-6} \mathrm{~g} / \mathrm{ml}$ of $\mathrm{PGA}_{2}$ or $\mathrm{PGB}_{2}$ also depressed the contractile

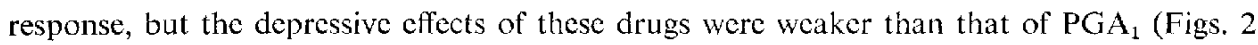
and 3). As previously reported (16), $\mathrm{PGE}_{1}$ and $\mathrm{PGE}_{2}$ in the dose of $10^{-6} \mathrm{~g} / \mathrm{ml}$ strongly depressed the contractile response. The depressive effect of $\mathrm{PGE}_{1}$ was more potent than that of $P G E_{2}$ (Fig. 4). $\mathrm{PGF}_{2 \kappa}$ had a slight depressive effect on the contractile response (Fig. 4). The order of the potencies of the depressive effect was as follows; $\mathrm{PGE}_{1}>\mathrm{PGE}_{2}>$ $\mathrm{PGA}_{1}>\mathrm{PGA}_{2} \div \mathrm{PGB}_{2} \div \mathrm{PGF}_{2 \alpha}$. The depressive effects of $\mathrm{PG}$ on the contractile response to the transmural nerve stimulation disappeared after washout of $P G$.

III. Effect of indomethacin on the contractile response to exogenously administered ACh and transmural nerve stimulation

Indomethacin in a dose of $10^{-s} \mathrm{~g} / \mathrm{m}$ l slightly reduced the muscular tone of some of the strips. Pretreatment (30 min before) with indomethacin in a dose of $10^{\circ \mathrm{g}} \mathrm{g} / \mathrm{ml}$, potentiated the contractile response to exogenously administered $\mathrm{ACh}$ (Fig. 5) and to the transmural nerve stimulation (Fig. 6). $\mathrm{PGE}_{1}$ in a dose of $10^{-6} \mathrm{~g} / \mathrm{ml}$ remarkably depressed the augmented contractile response to the transmural nerve stimulation in the presence of $10^{-6} \mathrm{~g} / \mathrm{ml}$ of indomethacin. However, the increase of the dose of indomethacin to $10^{-5} \mathrm{~g} / \mathrm{ml}$ attenuated its enhancing effect on the contractile response to exogenously administered $\Lambda \mathrm{Ch}$ (not shown in figure) and to transmural nerve stimulation (Fig. 6). 


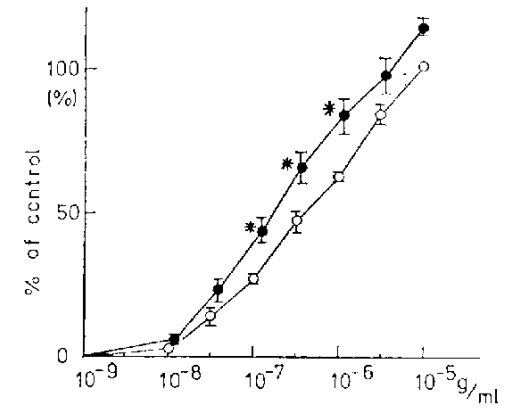

FIG. 5. Effect of pretreatment ( $30 \mathrm{~min}$ before) with indomethacin on the contractile response of isolated tracheal muscle to exogenously administered $\mathrm{ACh}$ in dogs. Ordinate; $\%$ of the control (the height of contraction induced by $10^{-5} \mathrm{~g} / \mathrm{ml}$ of $\mathrm{ACh}$ was 100). Abscissa; doses of $\mathrm{ACh}$ $(\log \mathrm{g} / \mathrm{ml}) . \bigcirc \quad O ;$ Control (untreated) group. - Indomethacin $\left(10^{-15}\right.$ $\mathrm{g} / \mathrm{ml}$ ) treated group. Each point shows the mean $=$ standard error (Number of animals $=4$ ). $* \mathrm{P}<0.05$; the difference between the values obtained in the same dose of ACh was statistically significant.

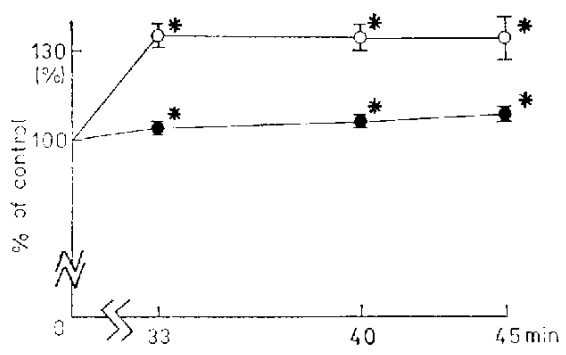

FiG. 6. Effect of pretreatment with indomethacin on the contractile response of isolated tracheal muscle to field stimulation. Ordinate; $\%$ of the control (the height of contraction induced by field stimulation before drug administration was 100). Abscissa; time course after drug administration (min). $\bigcirc-\cdots$; Indomethacin $\left(10^{-6} \mathrm{~g} / \mathrm{ml}\right)$ treated group. - Indomethacin $\left(10^{-5} \mathrm{~g} / \mathrm{ml}\right)$ treated group. Each point shows the meantstandard crror (Number of animals $=4$ ). " $\mathrm{P}<0.05$; significantly differcd from the control.

\section{DISCUSSION}

Existence of a feedback control mechanism in sympathetic nerve transmission through endogenous PGE series has been suggested (10). A similar mechanism has also been suggested in parasympathetic nerves (12). Our previous study showed that contractile response of the isolated canine tracheal muscle to the transmural nerve stimulation was predominantly mediated through cholinergic nerves (16). $\mathrm{PGE}_{1}$ and $\mathrm{PGE}_{2}$ prevented contractile response to the transmural nerve stimulation, while the response to exogenously administered ACh was almost unaffected or was only slightly depressed. Therefore, the aforementioned fecdback control mechanism may work in parasympathetic nerves innervating canine tracheal muscle. Comparison with other PGs, PGE series, particularly $\mathrm{PGE}_{1}$ had the most potent inhibitory action on sympathetic nerves (2) and parasympathetic nerves $(12,14,17)$ in the heart. The present study also demonstrated that the PGE series was the most potent inhibitory substance among PGs. Therefore, it seems that, if the feedback mechanism does exist in the autonomic nerves, PGE series is a specific substance involved in the mechanism. The resting tone of the tracheal muscle used in the present study was low, and $\mathrm{PGE}_{1}$ produced a relaxation only when the muscular tone was elevated by ACh. The finding is consistent with the results that PGs caused relaxation, when the muscle had an isometric tone (18). Türker and Khairallah (19) also observed that in a dose of over $0.5 \times 10^{-9} \mathrm{~g} / \mathrm{ml} \mathrm{PGE}_{1}$ produced a relaxation in the muscle contracted by $10^{-8} \mathrm{~g} / \mathrm{ml}$ of $\mathrm{ACh}$. In contrast to $\mathrm{PGE}_{1}, \mathrm{PGF}_{2 \alpha}$ produced a contraction in human bronchial muscle (20). However, $\mathrm{PGF}_{2 \alpha}$ did not contract canine tracheal muscle. 
Indomethacin inhibits the biosynthesis of PGs (21). In the presence of indomethacin, the contractile response to the transmural nerve stimulation was considerably potentiated, and such may be due to a partial removal of the negative feedback control through the PGE series (22). However, at least in part, indomethacin may act on postsynaptic sites since exogenously administered $\mathrm{ACh}$ was also potentiated by the drug. The potentiating effect of indomethacin on both nerve-mediated and $\mathrm{ACh}$-induced contraction wcakened as the administered dose was increased. Farmer et al. (23) also reported that the biphasic action of indomethacin on $\mathrm{PGF}_{2 \alpha}$-induced contraction in guinea pig tracheal muscle, i.c. the small dose produced a potentiation and the large dose, an inhibition.

Acknowledgement: The authors would like to thank Mr. H. Mori (Ono Pharmaceutical Co. Ltd.) for providing the prostaglandins.

\section{REFERENCES}

1) Hedquist, P. And Wenvmalm, A.: Inhibition by prostaglandin $E_{1}$ of the sympathetic ncuromuscular transmission in the rabbit heart. Acta physiol. scand. 79, 19A-20A (1970)

2) Hedovist, P., Stü̈rne, L. A.sd Wexnmalm, A.: Inhibition by prostaglandin $E_{2}$ of sympathetic neurotransmission in the rabbit heart. Acta plysiol. scand. 79, 139-141 (1970)

3) HtDovist, P.: Studies on the effect of prostaglandin $E_{1}$ and $E_{2}$ on the sympathetic nueromuscular transmission in some animal tissues. Acta physiol. scand. Suppl. 345, 1-40 (1970)

4) Hedquist, P. and Wleynmalm, Â.: Comparison of the effect of prostaglandin $E_{1}, E_{2}$ and $\mathrm{F}_{2 e}$ on the sympathelically stimulated rabbit heart. Acta physiol. scard. 83, 156-162 (1971)

5) WenNiat.M, A.: Studies on mechanisms controlling the secretion of neurotransmitters in the rabbit heart. Acta physiol. scand, 365, 1-36 (1971)

6) HLDQvist, P.: Control by prostaglandin $\mathrm{E}_{2}$ of sympathetic neurotransmission in the spleen. Life Sci. 9, 269-278 (1970)

7) Von Eul.F, U.S. AND HedQvist, P.: Inhibitory action of prostaglandin $F_{1}$ and $E_{2}$ on the neuromuscular transmission in the guinca-pig vas deferens. Acta physiol. scand. 77, $510-512(1969)$

8) Sw LDIs, G.: Endogenous possibly prostaglandin-mediated inhibition of the neuromuscular transmission in the vas deferens. J. Pinarm. Pharmacol. 23, 994-995 (1971)

9) Hedquist, P.: Inhibition by prostaglandin $E_{1}$ of vascular response to sympathetic nerve stimulation in vivo. Acta physiol. seand. 80, 6A (1970)

10) Hedquist, P.: Autonomic neurotransmission. The Prostaglandins, Edited by Ramwell, P.W., Vol. 1, p. 101, Plenum Press, New York (1973)

11) Coctani, F., Pacf-Asciak, C., Volta, F. AND Wolfe, L.S.: Effect of nerve stimulation on prostaglandin formation and release from the rat stomach. Am. J. Physiol. 213, 10561064 (1964)

12) Wennmalm, $\AA$. and Hedquist, P.: Inhibition by prostaglandin $E_{1}$ of parasympathetic neurotransmission in the rabbit heart. Life Sci. 10, 465-470 (1971)

13) Junstad, M. AND Wennmalm, $\dot{A}$ : Release of prostaglandin from the rabbit isolated heart following vagal nerve stimulation or acetylcholine infusion. Brit. J. Pharmacol. 52, 375-379 (1974)

14) Feniuk, W. AND LARgf, B.J.: The effects of prostaglandins $E_{1}, E_{2}$ and $F_{2 \varepsilon}$ on vaga bradycardia in the anestlietized mouse. Brit. J. Pharmacol. 55, 47-49 (1975)

15) MaIN, I.H.M.: The inhibitory actions of prostaglandins on respiratory smooth muscle. Brit. J. Pharmacol. 22, 511-519 (1964)

16) Nakanishi, H., Yoshida, H. ANd SUzUki, T.: Inhibitory effects of prostaglandin $E_{1}$ and $\mathrm{E}_{2}$ on cholinergic transmission in isolated canine tracheal muscle. Japan. J. Pharmacol. 
26, 669-674 (1976)

17) HaDflacy, P., ILLes, P. AN.J K vol. I, J.: The effects of PGE $\mathrm{PG}_{1}$ responses to cardiac vagus nerve stimulation and acetylcholine release. Europ. J. Pharmacol. 23, 251-255 (1973)

18) Yamagiceni, T., 11ITZIG, B. AND Coburn, R.F.: Endogenous prostaglandins and mechanical tcnsion in canine tracheal muscle. Am. J. Physiol. 230, 1737-1743 (1976)

19) Turker, R.K. and Khatralliail, P.A.: Prostaglandin $E_{1}$ action on canine isolated tracheal musclc. J. Pharm. Pharmacol. 21, 498-501 (1969)

20) Sweatman, W.J.F. ANd Collier, II.O.J.: Effects of prostaglandins on human bronchial muscle. Natrire 217, 69 (1968)

21) Flower, R.J.: Drugs which inhibit prostaglandin biosynthesis. Pharmacol. Rev. 26, 33-67 (1972)

22) Fredholm, B. AND Hedovist, P.: Increased relcase of noradrenaline from stimulated guinea-pig vas deferens after indomethacin treatment. Acta physiol. scand. 87, 570-572 (1973)

23) Farmir, J.B., Farrar, D.G. AND WILSON, J.: Antagonism of tone and prostaglandinmediated responses in a tracheal preparation by indomethacin and SC-19220. Brit. J. Pharmacol. 52, 559-565 (1974) 